\title{
Dispersion Model of Total Suspended Particulate from Tanjung Jati B Jepara Coal-Fired Power Plant's Chimneys
}

\author{
Poerna S. Oetari ${ }^{1, *}$, Sudharto P. Hadi ${ }^{1}$, and Haryono S. Huboyo ${ }^{2}$ \\ ${ }^{1}$ Doctoral Program of Environmental Science, School of Postgraduate Studies, Diponegoro University, Semarang - Indonesia \\ ${ }^{2}$ Department of Environmental Engineering, Faculty of Engineering, Diponegoro University, Semarang - Indonesia
}

\begin{abstract}
The study of dispersion model of total suspended particulate at Tanjung Jati B Jepara coal-fired power plants chimney. The chimney is using coal as the fuel with 4 (four) unit with $4 \mathrm{X}$ 660 MW capacity. In 2016, the wind direction was dominant from east- southeast with $5,-8.8 \mathrm{~m} / \mathrm{s}$ speed,, and in 2017 ,, the wind direction was dominant to the southeast with $5,7-8.8 \mathrm{~m} / \mathrm{s}$ speed. The analysis of dispersion is using AEROMOD model. The result of the dispersion model of total suspended particulate in two years from all chimney is expanding with the maximum ground level consentration increasing from $11.4 \mu \mathrm{g} / \mathrm{m}^{3}$ to $19,5 \mu \mathrm{g} / \mathrm{m}^{3}$. The result of the dispersion is spreading till the residential area near the power plant.
\end{abstract}

Keywords: Total Suspended Particulate, Coal, Power Plant, AEROMOD Model, Dispersion.

\section{Background}

Development of coal-based energy is oen of significant implementation in energy policy to foster the diversification of energy development toward towards energy resilience and security. It is a wide range for aspect of energy resilience, in the perspective of engingeering, the resilience can be define such as how technology, mathematic model applied in energy producing of energy such as in electricity resilicen modelling [1]. In the social perspective, energy resilience explored the community such as how people use energy in their daily live, and how the concern sustainability of their energy [2]. In th coal base energy development, Combining aspect in energy resilience and security such as monitoring in environmental aspect, should be recorded routine as of behaviroal activity to ensure the energy development environmentally sound, not only in the engineering side but also in the community live.

One of the activities in energy sector is the provision of electricity for the society. It is globally dominated by energy conversion technology which in the form of fossil fuel, coal. Coal as solid fuel is hard to be mixed with air in the first stage of burning process, the process caused imperfect burning process the produce air pollutant [3]. The burning process of coal in the thermal power plant produces carbon dioxide (CO2), sulfur oxide (Sox), nitrogen oxide (NOx); another trace of CFC gases and air organic particulate such as fly ash and suspended particulate matter (SPM). CO2, NOx and CFC are greenhouse gases (GHGs). The high content of ash in low quality coal and the inefficient burning process are contributed to the air emission particle and another gases including the gas that cause greenhouse effect [4].

With the increasement of the population who live near the power plant of Tanjungjati B Jepara, unit 1,2,34, the residential area become at risk with the dispersion of dust particle. The transport ability of air that can transport dust particle influence human's health significantly $[5,6,7]$.
The residential area near the power plant become at risk due to the dust particle. Receptor from emission that will enter the air ambient is influenced by the condition of climatology and not because of distance. The observation of desperation of dust particle can be seen in the study using AEROMOD VIEW model.[3].

\section{Methodology}

Tanjung Jati B (TJB) Power Plant has 4 units of coal-fired generators, each of it has 660 MW capasity. Tanjung Jati B (TJB) Power Plant Located in Dusun Sekuping, Desa Tubanan, Kecamatan Kembang, Kabupaten Jepara, Central Java. This power plant occupies 152 ha of land for units $1 \& 2$ of and 83.6 ha for unit $3 \& 4$ the total area is 235.6 ha. Unit $1 \& 2$ started the operation in 2006, unit 3 in 2011, and unit 4 in 2012. The study is conducted in three residential area near the power plant of Tanjung Jati B Jepara namely, Jambu Timur Village (RT1), Jeruk Wangi Village (RT2 ) and Jambu Timur Village (RT3). The pattern of dispersion of TSP is conducted by using AEROMOD model, gauss dispersion model. The function of gauss dispersion model is to see the dispersion of pollution in rural and urban area, flat and complex area, flat and relevance area and another area (including point area and source volume) $[8,9]$.

\section{Result and Discussion \\ 3.1 Condition of TSP in Emission Source}

Concentration data from total suspended particulate is recorded from CEMS (Continuous Emission Monitoring System). This research analysis data of the concentration in the two term of investigation, first one in the quarter of 2016 and the second one is the quarter of 2017. CEMS is a sampling system, conditioning, analytic component, and software which is designed to provide the measurement of pollutant concentration directly, real-time, and continuously by analyzing the representative sample from exhaust gas. [10,11]. 
Table 1. Emission Source Profile

\begin{tabular}{|c|c|c|c|c|c|c|}
\hline \multirow{2}{*}{ Years } & \multirow[t]{2}{*}{$\mathbf{Q}$} & \multicolumn{4}{|c|}{$\begin{array}{c}\text { TSP Concentration (CEMS) } \\
(\mathbf{m g} / \mathbf{N m} 3)\end{array}$} & \multirow{2}{*}{$\begin{array}{l}\text { Standard* } \\
(\mathrm{mg} / \mathrm{Nm} 3)\end{array}$} \\
\hline & & C1 & $\mathrm{C} 2$ & $\mathbf{C 3}$ & $\mathrm{C4}$ & \\
\hline \multirow{4}{*}{2016} & I & 6,5 & 6,7 & 23,8 & 22,6 & \multirow{8}{*}{100} \\
\hline & II & 12,1 & 13,7 & 21,6 & 22,2 & \\
\hline & III & 11,7 & 10,1 & 20,9 & 21 & \\
\hline & IV & 10,9 & 8,0 & 20,8 & 20,6 & \\
\hline \multirow{4}{*}{2017} & I & 11,4 & 12,3 & 22 & 22,8 & \\
\hline & II & 10,3 & 8,6 & 23,1 & 22 & \\
\hline & III & 8,8 & 6,3 & 20,1 & 20,2 & \\
\hline & IV & 14,8 & 8,8 & 20,1 & 20,1 & \\
\hline \multicolumn{7}{|c|}{ Physical Parameters } \\
\hline \multicolumn{4}{|c|}{ Flow rate } & \multicolumn{3}{|c|}{$12,5 \mathrm{~m} / \mathrm{s}$} \\
\hline \multicolumn{4}{|c|}{ Chimney's Diameter } & \multicolumn{3}{|c|}{$7,9 \mathrm{~m}$} \\
\hline \multicolumn{4}{|c|}{ Chimney's Height } & \multicolumn{3}{|c|}{$240 \mathrm{~m}$} \\
\hline \multicolumn{4}{|c|}{ Exit Gas Temperature } & \multicolumn{3}{|c|}{$328^{\circ} \mathrm{K}$} \\
\hline \multicolumn{4}{|c|}{ Chimney 1 Coordinate } & \multicolumn{3}{|c|}{$\begin{array}{c}110^{\circ} 44^{\prime} 40.66^{\prime \prime} \mathrm{BT} ; 6^{\circ} 26^{\prime} \\
41.74 \text { " LS }\end{array}$} \\
\hline \multicolumn{4}{|c|}{ Chimney 2 Coordinate } & \multicolumn{3}{|c|}{$\begin{array}{c}110^{\circ} 44^{\prime} 32.6^{\prime \prime} \text { BT ; } 6^{\circ} 26^{\prime} \\
41.32 \text { " LS }\end{array}$} \\
\hline
\end{tabular}

Source: Monitoring Data PLTU Tanjung Jati B

*) Based on the regulation from the ministry of environment No. 21, 2008 about quality standard of immovable emission for business and/or thermal power plant activity.

\subsection{Wind Rose}

Climatology data in AERMODE mode which is used to modelled dispersion of Total Suspended Particulate is the direction and velocity data of air with measurement per hour in a year, and the modeled year is 2016 and 2017. The direction and velocity data of air is represented in the form of windrose analysis

\subsection{Result of Dispersion Model AEROMOD View}

Total suspended particulate from the monitoring in the quarter of 2016 and 2017 which was coming from CEMS with the dispersion pattern using AEROMODE showed different results. The observation of dispersion pattern in 2016 can be seen in one village, Jinggotan Village (R3) from the result of the dispersion pattern quarter I, II, III and IV have higher concentration level compare to the other two villages. Jambu Timur Village (R1) shows that it has the lowest concentration. In the observation of dispersion pattern in 2017 it still have the same tendency, but the concentration total suspended particulate is was increasing in 2016 with maximum ground level $7.43 \mu \mathrm{g} / \mathrm{m}^{3}-10.510 \mu \mathrm{g} / \mathrm{m}^{3}$ and in 2017 , the maximum ground level increase up to $10 \mu \mathrm{g} / \mathrm{m}^{3}-20.510 \mu \mathrm{g} / \mathrm{m}^{3}$. Detail of the measurement model describe in APPENDIX-1.

\section{Conclusion}

With the result in 2016, with the direction of the wind was dominant to east-south east and 2017 with direction of the wind to southeast, it is resulted dispersion analysis using AEROMOD view can be seen till the residential area near the power plant. Dispersion in quarter resulted fluctuation dispersion total suspended particulate in two years from the emission of all chimney, wider and the concentration increase. The highest concentration is in R3 area (Jinggotan Village) 1 $\mu \mathrm{g} / \mathrm{m}^{3}-3 \mu \mathrm{g} / \mathrm{m}^{3}$.

Base on the standard quality of air ambient, concentration of dust particle in the residential area with the value under standard quality because the power plant conducted environment management with particulate removal. Precombustion and post-combustion control with the right technology approach provides the ability to reduce carbon and dust particles and other air pollutants that are responsible for the greenhouse effect.

\section{References}

[1] Zaijing, G, and Liang D., The resilience evaluation model of electricity system., $7^{\text {th }}$ International Conference on Industrial Technology and Management (ICITM), IEEE, (2018).

[2] Maryono, Wijaya H B, Widjonarko, Pangi, Energy Resilience Assesment by Using SEM Approah in Central Java Province, Indonesia, Procedia-Social and Behavioral Sciences 227, pp. 146-151, (2016).

[3] J. Zhang and K. R. Smith, "Household air pollution from coal and biomass fuels in China: Measurements, health impacts, and interventions," Environ. Health Perspect., vol. 115, no. 6, pp. 848-855, 2007.

[4] A. Shamshad, M. H. Fulekar, and P. Bhawana, "Impact of Coal Based Thermal Power Plant on Environment and its Mitigation Measure," Int. Res. J. Environ. Sci., vol. 1, no. 4, pp. 60-64, 2012.

[5] M. M. Mokhtar, M. H. Hassim, and R. M. Taib, "Health risk assessment of emissions from a coal-fired power plant using AERMOD modelling," Process Saf. Environ. Prot., vol. 92, no. 5, pp. 476-485, 2014.

[6] J. S. Brown, T. Gordon, O. Price, and B. Asgharian, "Thoracic and respirable particle definitions for human health risk assessment," Part. Fibre Toxicol., vol. 10, no. 1, p. $12,2013$.

[5] J. Löndahl et al., "A set-up for field studies of respiratory tract deposition of fine and ultrafine particles in humans," J. Aerosol Sci., vol. 37, no. 9, pp. 1152-1163, 2006.

[7] L. Maria et al., "Atmospheric Pollution Research Methodological guide for implementation of the AERMOD system with incomplete local data," Atmos. Pollut. Res., vol. 1, no. 2, pp. 102-111, 2010.

[8] G. Norris, R. Duvall, S. Brown, and S. Bai, "EPA Positive M atrix Factorization (PMF) 5.0 Fundamentals and User Guide," p. 136, 2014.

[9] Pemerintah Daerah Provinsi Jawa Tengah, 2001. Keputusan Gubernur Jawa Tengah Nomor 8 Tahun 2001 tentang Baku Mutu Kualitas Udara Ambien. Sekretariat Daerah, Jawa Tengah.

[10] J. Schakenbach, R. Vollaro, R. Forte, J. Schakenbach, R. Vollaro, and R. Forte, "Fundamentals of Successful Monitoring, Reporting, and Verification under a Capand-Trade Program Fundamentals of Successful Monitoring, Reporting, and Verification under a Capand-Trade Program," vol. 2247, 2012.

[11] Kementerian Negara Lingkungan Hidup, 2008. Peraturan Menteri Negara Lingkungan Hidup Nomor 21 Tahun 2008 tentang Baku Mutu Emisi Sumber Tidak Bergerak Bagi Usaha dan/atau Kegiatan Pembangkit Listrik Tenaga Termal. Jakarta. 


\section{APPENDIX-1 AERMOD View Result}

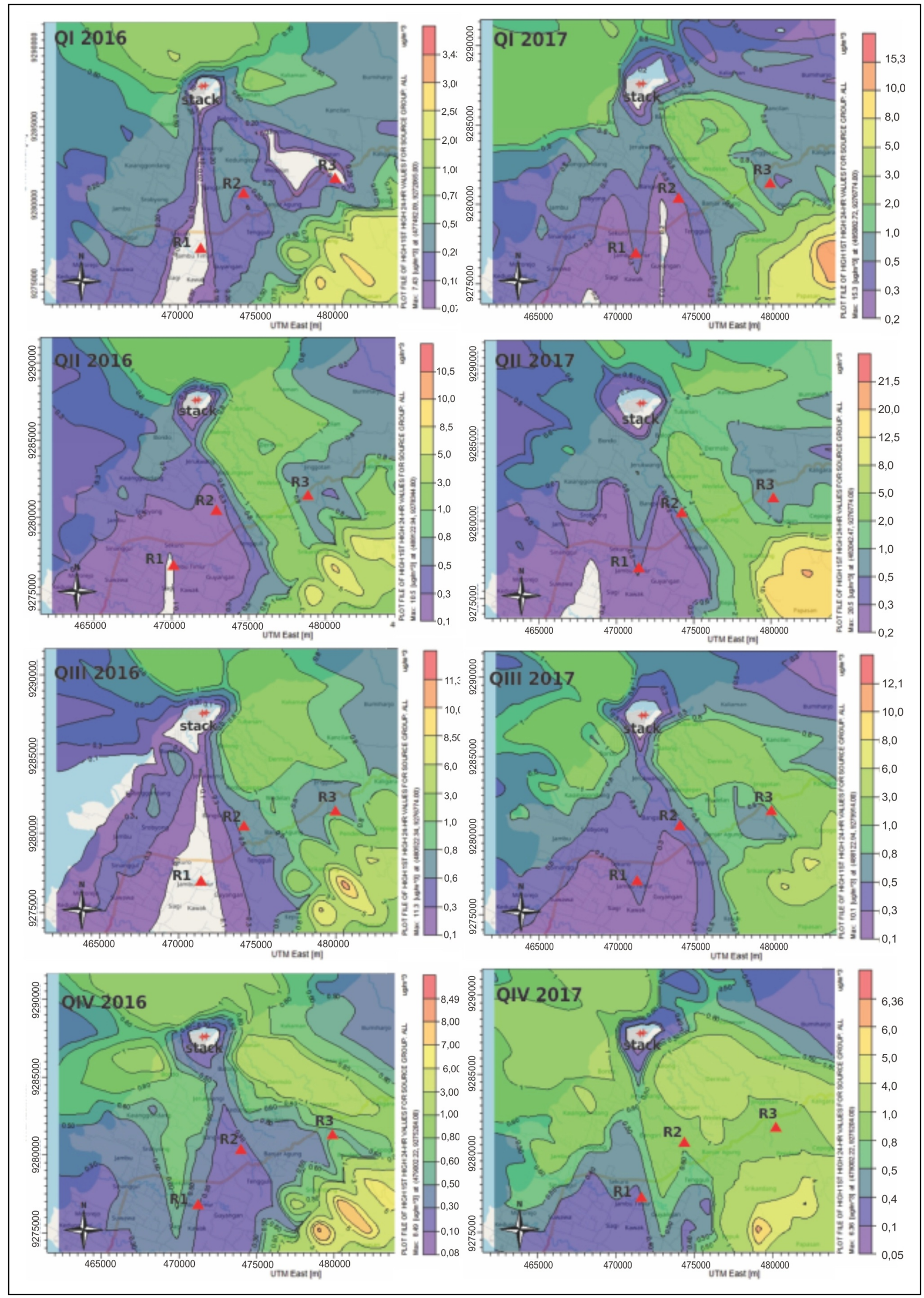

